\title{
Effects of Toona sinensis Leaf Extract and Its Chemical Constituents on Xanthine Oxidase Activity and Serum Uric Acid Levels in Potassium Oxonate-Induced Hyperuricemic Rats
}

\author{
Heung Joo Yuk ${ }^{1,+}$, Young-Sil Lee ${ }^{1,+}$, Hyung Won Ryu ${ }^{2}$, Seung-Hyung Kim ${ }^{3}[$ and \\ Dong-Seon Kim ${ }^{1, *}$ \\ 1 Herbal Medicine Research Division, Korea Institute of Oriental Medicine (KIOM), Daejeon 34054, Korea; \\ yukhj@kiom.re.kr (H.J.Y.); rheeys04@kiom.re.kr (Y.-S.L.) \\ 2 Natural Medicine Research Center, Korea Research Institute of Bioscience and Biotechnology (KRIBB), \\ Cheongju, Chungbuk 28116, Korea; ryuhw@kribb.re.kr \\ 3 Institute of Traditional Medicine and Bioscience, Daejeon University, Daejeon 34520, Korea; sksh518@dju.kr \\ * Correspondence: dskim@kiom.re.kr; Tel.: +82-42-868-9639 \\ + These authors contributed equally to this work.
}

Received: 15 November 2018; Accepted: 8 December 2018; Published: 9 December 2018

check for updates

\begin{abstract}
Toona sinensis leaf is used as a seasonal vegetable in Korea. A $70 \%$ ethanol extract of these leaves exhibited potent xanthine oxidase $(X O)$ inhibition, with a $50 \%$ inhibitory concentration $\left(\mathrm{IC}_{50}\right)$ of $78.4 \mu \mathrm{M}$. To investigate the compounds responsible for this effect, bioassay-guided purification led to the isolation of five constituents, identified as quercetin-3-O-rutinoside, quercetin-3-O- $\beta$-D-glucopyranoside, 1,2,3,4,6-penta- $O$-galloyl- $\beta$-D-glucopyranose (compound 3), quercetin-3-O- $\alpha$-L-rhamnopyranoside, and kaempferol-3-O- $\alpha$-L-rhamnopyranoside. Compound 3 showed the most potent inhibition of $\mathrm{XO}$, with an $\mathrm{IC}_{50}$ of $2.8 \mu \mathrm{M}$. This was similar to that of allopurinol $\left(\mathrm{IC}_{50}=2.3 \mu \mathrm{M}\right)$, which is used clinically to treat hyperuricemia. Kinetic analyses found that compound 3 was a reversible noncompetitive $\mathrm{XO}$ inhibitor. In vivo, the T. sinensis leaf extract $(300 \mathrm{mg} / \mathrm{kg})$, or compound $3(40 \mathrm{mg} / \mathrm{kg})$, significantly decreased serum uric acid levels in rats with potassium oxonate-induced hyperuricemia. Furthermore, ultraperformance liquid chromatography-quadrupole time-of-flight mass spectrometry analysis identified a high level of compound 3 in the leaf extract. These findings suggest that T. sinensis leaves could be developed to produce nutraceutical preparations.
\end{abstract}

Keywords: Toona sinensis; xanthine oxidase; uric acid; hyperuricemia; ultraperformance liquid chromatography-quadrupole time-of-flight mass spectrometry

\section{Introduction}

Hyperuricemia results from overproduction or underexcretion of uric acid [1,2] and is characterized by high serum uric acid levels ( $>7 \mathrm{mg} / \mathrm{dL}$ in humans). This increases the precipitation of urate crystals in the joints and kidneys, causing gout and gouty arthritis [3]. Recent publications have shown that serum uric acid levels are associated with diseases such as metabolic syndrome, hypertension, and increased cardiovascular risk [4,5]. Xanthine oxidase $(X O)$ is an important enzyme that catalyzes the oxidation of hypoxanthine to xanthine and the subsequent oxidation of xanthine to uric acid (urate) in humans [6]. XO inhibitors such as allopurinol and febuxostat reduce uric acid synthesis and act as useful clinical treatments for hyperuricemia and gout [7,8]. However, these synthetic drugs also produce side effects such as skin rash, renal failure, renal toxicity, and allergic 
reactions. It would therefore be beneficial to develop alternative drugs with increased efficacy and fewer side effects.

Toona sinensis M.Roem. (also known as Cedrela sinensis in Asia) is a member of the Meliaceae family, which is widely distributed throughout the world. The young leaves of $T$. sinensis can be eaten as a seasonal vegetable. In addition, most parts of this plant, including the stem bark, root bark, and young shoots, have been used as medicinal resources in eastern Asia [9,10]. Previous studies have revealed that aqueous leaf extracts were protective against hydrogen peroxide-induced oxidative stress and DNA damage in Madin-Darby canine kidney cells [11]. Recently, a T. sinensis extract was also shown to enhance anti-influenza A (H1N1) viral effects via significant downregulation of adhesion chemokines [12]. Additionally, T. sinensis leaves are a well-known source of flavonoids, phenolic acids, retinoids, triterpenes, and vitamins: These compounds have potential health-promoting properties related to their antioxidant, anticancer, antidiabetes, and anti-inflammatory effects [13,14]. Many researchers have reported that compounds isolated from $T$. sinensis leaves contributed to their biological activities, but no detailed investigation of potential $\mathrm{XO}$ inhibitors has been carried out.

In the present study, we identified XO inhibitory properties and isolated five compounds (1-5) from $T$. sinensis leaves. Kinetic studies indicated that compound 3 exhibited the most potent inhibitory activity. We also studied the effects of the most abundant compound, (4), and the most potent XO inhibitor, (3), on serum uric acid levels in rats with potassium oxonate (PO)-induced hyperuricemia. In addition, our quantification of the compounds isolated from T. sinensis could inform quality assessment of $T$. sinensis leaf extracts.

\section{Results and Discussion}

\subsection{Bioassay-Guided Isolation and Structural Identification}

Extracts of T. sinensis leaves were prepared using different polar solvents (ethyl acetate [EtOAc], $70 \%$ ethanol in water $[70 \% \mathrm{EtOH}], \mathrm{H}_{2} \mathrm{O}$ ) and tested for $\mathrm{XO}$ inhibitory activity. Enzyme activity was assayed spectrophotometrically by determining uric acid formation at $295 \mathrm{~nm}$, using xanthine as the substrate [15]. As shown in Table 1, the $70 \% \mathrm{EtOH}$ extract of $T$. sinensis leaves (TSE) exhibited potent XO inhibition, with a $50 \%$ inhibitory concentration $\left(\mathrm{IC}_{50}\right)$ of $78.4 \mu \mathrm{g} / \mathrm{mL}$. We then investigated which active compounds were responsible for this effect. Activity-guided fractionation of TSE gave five compounds, which were purified using Diaion, octadecyl-functionalized silica gel, and Sephadex LH-20 column chromatography. The isolated compounds (1-5) were identified as quercetin-3-O-rutinoside (rutin, 1) [16], quercetin-3- $O$ - $\beta$-D-glucopyranoside (isoquercitrin, 2) [17], 1,2,3,4,6-penta-O-galloyl- $\beta$-D-glucopyranose (pentagalloyl glucose, 3) [18], quercetin-3-O- $\alpha$-L-rhamnopyranoside (quercetrin, 4) [19], and kaempferol-3-O- $\alpha$-L-rhamnopyranoside (afzelin, 5) [20], through analysis of our spectroscopic data $\left({ }^{1} \mathrm{H}\right.$ - and ${ }^{13} \mathrm{C}$-nuclear magnetic resonance (NMR) and high resolution electrospray ionization (HRESI)-MS, Supplementary Materials) and by comparison to previous literature. The structures of the compounds isolated from T. sinensis leaves are shown in Figure 1. 
Table 1. Inhibitory effects of the leaf extract of Toona sinensis using different solvents and isolated compounds $\mathbf{1}-\mathbf{5}$ on xanthine oxidase activities.

\begin{tabular}{lccc}
\hline \multirow{2}{*}{ Compound } & \multicolumn{3}{c}{ Xanthine Oxidase } \\
\cline { 2 - 4 } & $\mathbf{I C}_{\mathbf{5 0}}{ }^{\mathbf{a}}$ & Inhibition $\mathbf{\%}$ & Kinetic Mode $\left.^{\mathbf{b}} \boldsymbol{K}_{\mathbf{i}}{ }^{\mathbf{c}}, \boldsymbol{\mu} \mathbf{M}\right)$ \\
\hline EtOAc & $>500 \mathrm{ppm}$ & $8.4 \pm 0.8$ & $\mathrm{NT}^{\mathrm{d}}$ \\
$70 \%$ Ethanol & $78.4 \pm 2.4 \mathrm{ppm}$ & $74.2 \pm 1.2$ & $\mathrm{NT}$ \\
$\mathrm{H}_{2} \mathrm{O}$ & $284.7 \pm 5.1 \mathrm{ppm}$ & $53.7 \pm 1.6$ & $\mathrm{NT}$ \\
$\mathbf{1}$ & $>100 \mu \mathrm{M}$ & $42.9 \pm 1.4$ & $\mathrm{NT}$ \\
$\mathbf{2}$ & $>100 \mu \mathrm{M}$ & $47.8 \pm 1.1$ & $\mathrm{NT}$ \\
$\mathbf{3}$ & $2.79 \pm 0.2 \mu \mathrm{M}$ & $96.4 \pm 0.7$ & Noncompetitive $(3.1)$ \\
$\mathbf{4}$ & $>100 \mu \mathrm{M}$ & $38.9 \pm 1.9$ & $\mathrm{NT}$ \\
$\mathbf{5}$ & $>100 \mu \mathrm{M}$ & $31.7 \pm 1.3$ & NT \\
Allopurinol & $2.28 \pm 0.3 \mu \mathrm{M}$ & $>98$ & Competitive \\
Oxypurinol & $28.4 \pm 0.5 \mu \mathrm{M}$ & $87.6 \pm 0.9$ & NT \\
\hline
\end{tabular}

a All compounds were examined in a set of experiments repeated three times; ${ }^{\mathrm{b}}$ sample concentration was $200 \mathrm{ppm}$ $\left(\mu \mathrm{g} / \mathrm{mL}\right.$ ) for the extract and $100 \mu \mathrm{M}$ for each compound; ${ }^{\mathrm{c}}$ values of inhibition constant; ${ }^{\mathrm{d}} \mathrm{NT}$ is not tested; IC is inhibitory concentration.

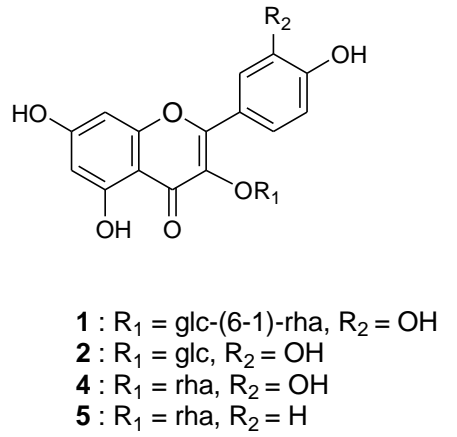<smiles></smiles>

Figure 1. Chemical structures of isolated compounds $(\mathbf{1}-\mathbf{5})$ from the leaves of $T$. sinensis.

Pentagalloyl glucose (3), the precursor of gallotannin, can be found in several medicinal plants [21], and this was the most effective $\mathrm{XO}$ inhibitor. Compound $\mathbf{3}$ was obtained as a white power with a molecular formula of $\mathrm{C}_{41} \mathrm{H}_{32} \mathrm{O}_{26}$ and 26 degrees of unsaturation, established by HRESI-MS ([M - H] $]^{-}$ at $m / z$ 939.1119, calcd for $\mathrm{C}_{41} \mathrm{H}_{31} \mathrm{O}_{26} 939.1104,1.6$ ppm error). The ${ }^{13} \mathrm{C}-\mathrm{NMR}$ data identified $15 \mathrm{C}-\mathrm{C}$ double bonds and five carbonyl groups, thus accounting for 20 of the 26 degrees of unsaturation. The remaining 6 degrees of unsaturation were ascribed to five aromatic rings and one sugar ring. In MS fragmentation analysis, compound 3 showed fragment ions at $m / z 787,769,617,465,313$, and 169 in the MS ${ }^{2}$ spectrum. This fragmentation pattern was consistent with previous reports [22]. Thus, compound 3 was identified as 1,2,3,4,6-penta-O-galloyl- $\beta$-D-glucopyranose.

\subsection{Contribution of the Identified Compounds to XO Inhibitory Activity}

Compounds 1-5 were evaluated for their inhibitory effects on XO activity. Both flavonol glycosides (1, 2, 4, and 5) and gallotannin (3) had concentration-dependent effects on XO activity (Figure 2A). Cos et al. reported that flavonoids such as quercetin and kaempferol had strong XO inhibitory effects [23]. However, our results showed that the flavonoid compounds $(\mathbf{1}, \mathbf{2}, \mathbf{4}$, and 5) were inactive $\left(\mathrm{IC}_{50}>100 \mu \mathrm{M}\right)$. These data were striking because this class of $\mathrm{XO}$ inhibitor did not behave in accordance with the usual trend, where glycosides usually show significantly less inhibitory potency than their aglycone counterpart. Among the five compounds, pentagalloyl glucose (3) exhibited the most potent inhibitory activity $(96.4 \%)$ at a concentration of $100 \mu \mathrm{M}$, followed by compounds 2 $(47.8 \%), \mathbf{1}(42.9 \%), 4(38.9 \%)$, and $\mathbf{5}(31.7 \%)$. The potency of compound $3\left(\mathrm{IC}_{50}=2.79 \mu \mathrm{M}\right)$ could be 
favorably compared to selective XO inhibitors currently used as therapeutics, including allopurinol $\left(\mathrm{IC}_{50}=2.28 \mu \mathrm{M}\right)$ [24]. It is known that allopurinol and oxypurinol (isosteres of hypoxanthine and xanthine, respectively) inhibit xanthine oxidase activity and limit the biosynthesis of uric acid. However, our results showed that oxypurinol $\left(\mathrm{IC}_{50}=28.4 \mu \mathrm{M}\right)$ was not as effective in inhibiting the activity of $\mathrm{XO}$ when compared to allopurinol. In regard to the affinity of $\mathrm{XO}$ for oxypurinol, Tamta et al. have also reported that oxypurinol showed a much lower inhibitory activity than allopurinol in XO screening [25]. The binding of oxypurinol to the reduced molybdenum site of the enzyme has been shown to be reversible and is released after reoxidation of the enzyme. Although the inhibitor binds very tightly to the enzyme, the inhibition is time dependent and requires some time for complete enzyme inhibition [26].
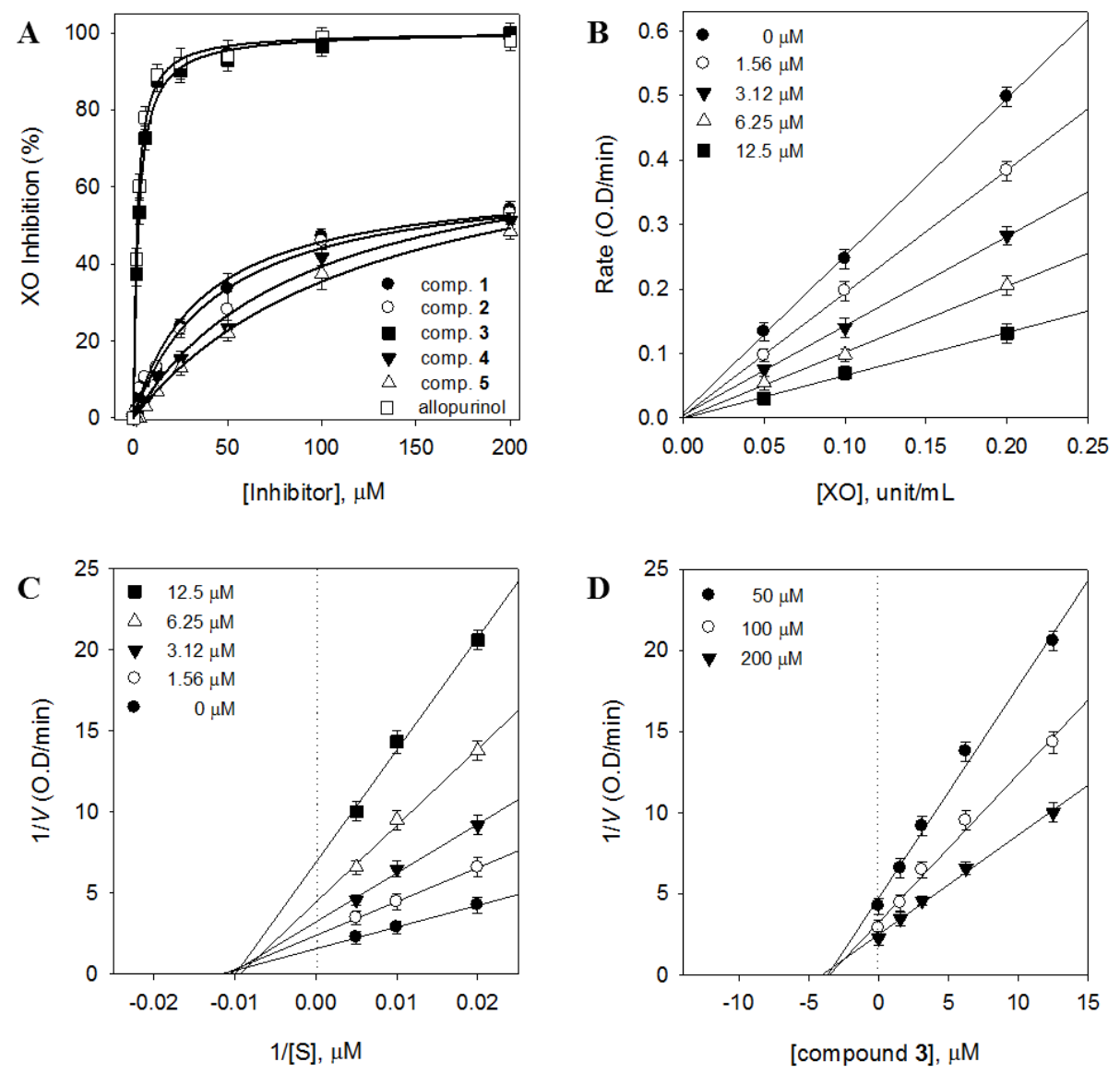

Figure 2. (A) Inhibitory effects of compounds (1-5) on the activity of xanthine oxidase $(X O)$ for the oxidation of xanthine to uric acid. (B) Catalytic activity of $\mathrm{XO}$ as a function of enzyme concentration at different concentrations of compound 3. (C) Lineweaver-Burk plots were constructed for the inhibition of $\mathrm{XO}$ by compound 3 . The plot is expressed as 1 /velocity versus 1 /xanthine (S) with or without an inhibitor in the reaction solutions. (D) Dixon plots of $\mathrm{XO}$ inhibition by compound 3. The graphical symbols are substrate concentrations $(50 \mu \mathrm{M}, \bullet ; 100 \mu \mathrm{M}, \bigcirc ; 200 \mu \mathrm{M}, \mathbf{\nabla})$.

As shown in Figure 2B, the effects of various concentrations of $3(0,1.56,3.12,6.25$, and $12.5 \mu \mathrm{M})$ on the activity of different $X O$ concentrations $(0,0.05,0.1$, and $0.2 \mathrm{unit} / \mathrm{mL})$ were analyzed. These data indicated that compound 3 acted as a reversible $\mathrm{XO}$ inhibitor. We subsequently analyzed the type of inhibition using both Lineweaver-Burk (Figure 2C) and Dixon (Figure 2D) plots. These analyses revealed that the $1 / y$-intercept $\left(V_{\max }\right)$ decreased, whereas the $-1 / x$-intercept $\left(K_{\mathrm{m}}\right)$ remained constant, as the compound concentration increased. This indicated that compound $\mathbf{3}$ acted as a noncompetitive inhibitor with an inhibition constant $\left(K_{\mathrm{i}}\right)$ value of $3.1 \mu \mathrm{M}$. 


\subsection{Serum Uric Acid Levels in Rats with PO-Induced Hyperuricemia}

The selective uricase inhibitor, $\mathrm{PO}$, is known to produce hyperuricemia by blocking the effects of hepatic uricase [27]. The effects of TSE and compound 3 on PO-induced hyperuricemic rats are shown in Figure 3. Serum uric acid levels were significantly increased in the PO-treated control rats, as compared to the normal control group $(p<0.005)$. The rats treated with TSE $(300 \mathrm{mg} / \mathrm{kg})$ or compound $3(40 \mathrm{mg} / \mathrm{kg})$ showed significant $(19.4 \%$ and $20.7 \%)$ reductions in their serum uric acid levels, as compared to the PO group (both $p<0.01$ ).

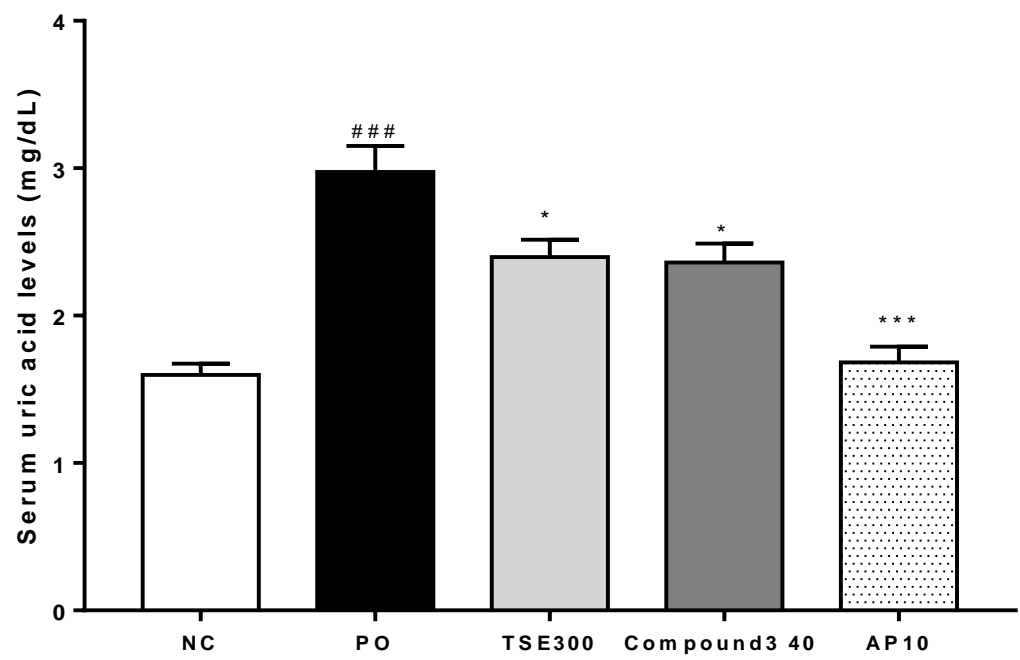

Figure 3. Effects of 70\% EtOH T. sinensis leaves (TSE) and compound 3 on serum uric acid levels in potassium oxonate (PO)-induced hyperuricemic rats. NC: normal control group; PO: potassium oxonate-induced hyperuricemia group; TSE-300: $300 \mathrm{mg} / \mathrm{kg} 70 \%$ EtOH TSE; AP-10: $10 \mathrm{mg} / \mathrm{kg}$ allopurinol. Data are expressed as the mean \pm SEM $(n=6)$; \#\#\# $p<0.001$ versus the NC group; ${ }^{*} p<0.05$ and ${ }^{* * *} p<0.005$ versus the PO group.

Rats treated with allopurinol $(10 \mathrm{mg} / \mathrm{kg})$ as a positive control showed a $43.5 \%$ decrease in their serum uric acid level $(p<0.005)$. Although compound 3 had a potent inhibitory effect on XO activity in vitro $\left(\mathrm{IC}_{50}=2.79 \mu \mathrm{M}\right)$, it did not reduce serum uric acid levels as effectively as allopurinol in vivo. The most abundant $T$. sinensis compound, 4 , had no effect on the serum uric acid level at $40 \mathrm{mg} / \mathrm{kg}$ (Supplementary Materials). Discrepancies between the in vitro and in vivo results may have reflected differences in bioavailability and pharmacokinetics in rats. It is also possible that structural differences, together with variations in absorption and metabolic characteristics of the various test compounds, may have led to the formation of metabolites with contrasting XO inhibitory activity.

\subsection{Ultraperformance Liquid Chromatography-Quadrupole Time-of-Flight Mass Spectrometry (UPLC-qToF MS) Profiles}

The constituents of TSE were analyzed using UPLC-qToF MS. As shown in Figure 4, complete chromatographic separation of these constituents was achieved within $13 \mathrm{~min}$. The identity of each peak in the UPLC trace was doubly verified by comparison to the retention time and the UV spectrum $\left(\lambda_{\max }\right)$ of the isolated pure compound. All detected peaks also showed molecular ions with masses consistent with the identified compounds $\left(\mathbf{1},[\mathrm{M}-\mathrm{H}]^{-}\right.$at $m / z$ 609.1448; 2, $m / z$ 463.0893; 3, $m / z$ 939.1119; 4, $m / z$ 447.0939; 5, $m / z$ 431.0974), as shown in Table 2. Extractions for quantitative analyses were performed using EtOAc, 70\% EtOH, or $\mathrm{H}_{2} \mathrm{O}$. The most abundant peaks (1-5) were observed using 70\% $\mathrm{EtOH}$. The levels of the five isolated compounds were analyzed by UPLC at $254 \mathrm{~nm}$ for the flavonoids $(\mathbf{1}, \mathbf{2}, \mathbf{4}$, and 5) and at $280 \mathrm{~nm}$ for the gallotannin (3). The standard curves were linear and reproducible for each of the isolated compounds, as evidenced by the correlation coefficients $\left(r^{2}=0.998-0.999\right)$. The levels of compounds 1-5 in TSE were determined as $0.69,1.32,1.34,7.12$, and $1.46 \mathrm{mg} / \mathrm{g}$ of dried 
sample, respectively. In a preliminary study, the extracts produced using EtOAc or $\mathrm{H}_{2} \mathrm{O}$ showed weak inhibitory effects on $\mathrm{XO}\left(\mathrm{IC}_{50}\right.$ values of $>500 \mu \mathrm{g} / \mathrm{mL}$ and $284.7 \mu \mathrm{g} / \mathrm{mL}$, respectively), and the levels of compounds 1-5 were also significantly lower than those present in 70\% EtOH TSE.

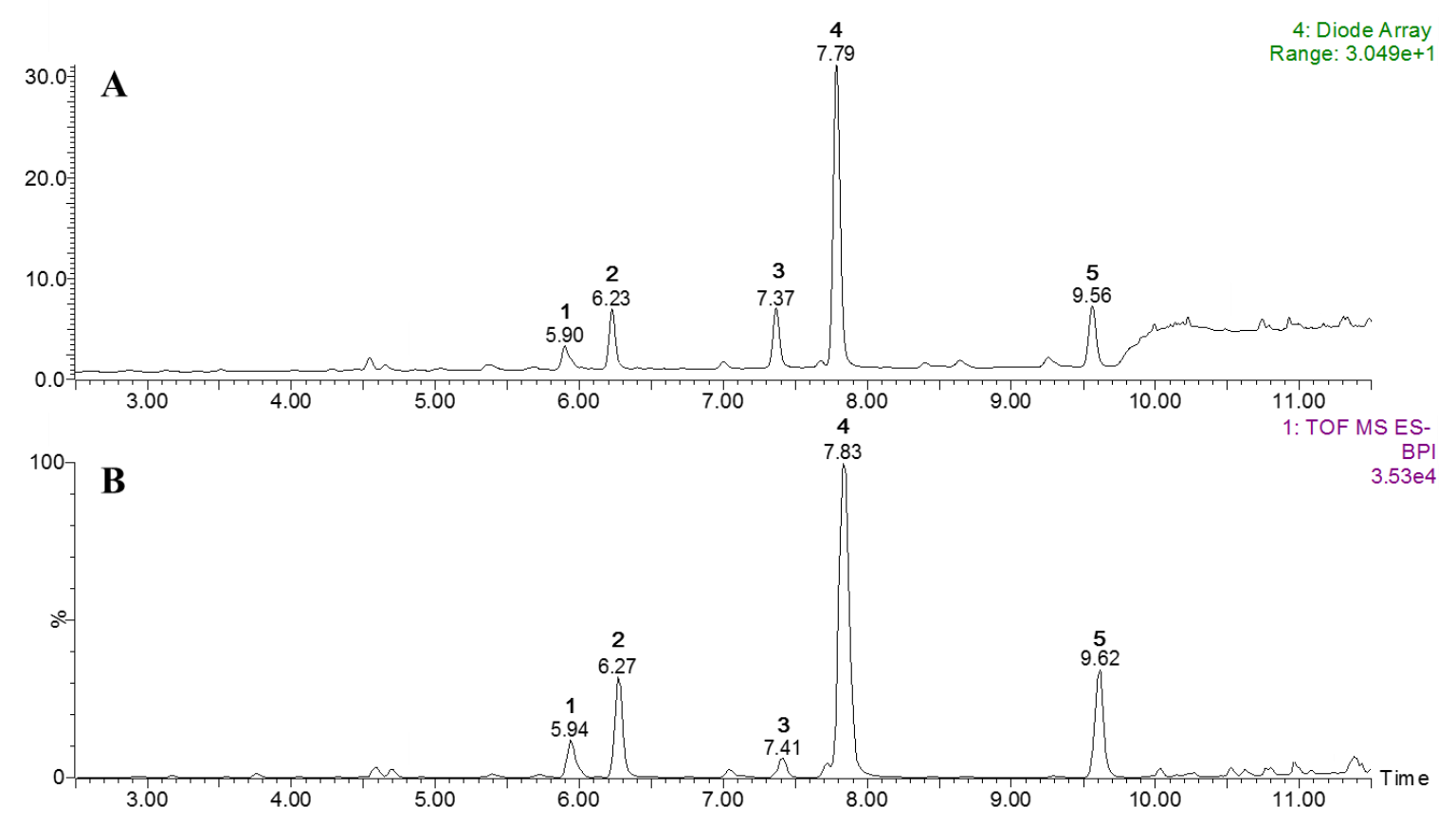

Figure 4. Representative chromatograms of $70 \% \mathrm{EtOH}$ extract from the leaves of $\mathrm{T}$. sinensis: (A) Photodiode array (PDA) chromatogram and (B) total ion current-base peak intensity (TIC-BPI) chromatogram.

Table 2. Spectral characteristics and contents $(\mathrm{mg} / \mathrm{g})$ of the five investigated compounds in the leaves of $T$. sinensis.

\begin{tabular}{|c|c|c|c|c|c|c|c|c|}
\hline \multirow{2}{*}{ Peak } & \multirow{2}{*}{$\begin{array}{c}t_{\mathrm{R}} \\
(\mathrm{min})\end{array}$} & \multirow{2}{*}{$\begin{array}{l}\lambda_{\max } \\
(\mathrm{nm})\end{array}$} & \multicolumn{3}{|c|}{ Dried Leaves $(\mathrm{mg} / \mathrm{g})^{a}$} & \multirow{2}{*}{$\begin{array}{c}{[\mathbf{M}-\mathbf{H}]^{-}(m / z)} \\
(\text { ESI-HRMS })\end{array}$} & \multirow{2}{*}{$\begin{array}{c}\text { Molecular Formula } \\
\text { (ppm Error) }\end{array}$} & \multirow{2}{*}{ Identification $^{b}$} \\
\hline & & & EtOAc & $70 \% \mathrm{EtOH}$ & $\mathrm{H}_{2} \mathrm{O}$ & & & \\
\hline 1 & 5.90 & $\begin{array}{l}254 \\
352\end{array}$ & $\operatorname{tr}$ & 0.69 & 0.71 & 609.1448 & $\mathrm{C}_{27} \mathrm{H}_{29} \mathrm{O}_{16}(-1.3)$ & Quer-3-O-Rut \\
\hline 2 & 6.23 & $\begin{array}{l}255 \\
353\end{array}$ & $\operatorname{tr}$ & 1.32 & 0.40 & 463.0893 & $\mathrm{C}_{21} \mathrm{H}_{19} \mathrm{O}_{12}$ (3.5) & Quer -3-O- $\beta$-D-Glc \\
\hline 3 & 7.37 & 279 & $\operatorname{tr}$ & 1.34 & 0.25 & 939.1119 & $\mathrm{C}_{41} \mathrm{H}_{31} \mathrm{O}_{26}$ (1.6) & PGG \\
\hline 5 & 9.56 & $\begin{array}{l}263 \\
344\end{array}$ & $\operatorname{tr}$ & 1.46 & 0.41 & 431.0974 & $\mathrm{C}_{21} \mathrm{H}_{19} \mathrm{O}_{10}(-0.9)$ & Kaem-3-O- $\alpha$-L-Rham \\
\hline
\end{tabular}

${ }^{a}$ All values are expressed as mean $(n=3)$; content expressed as mg of each compound equivalents per $\mathrm{g}$ of dry weight; $^{\text {b }}$ quer: quercetin; kaem: kaempferol; PGG: 1,2,3,4,6-penta-O-galloyl- $\beta$-D-glucopyranose; rut: rutinoside; glc: glucopyranoside; rham: rhamnopyranoside.

\section{Materials and Methods}

\subsection{Plant Materials and Sample Preparation}

T. sinensis leaves were collected at tree communities in Sacheon, South Korea, in May 2016. The collected leaves were identified, and a voucher specimen (KRIBB 0000583) was deposited in the Korea Research Institute of Bioscience and Biotechnology. The collected leaves were freeze-dried immediately after sampling and then ground to a powder and stored at $-75^{\circ} \mathrm{C}$ until further analysis. Three different solvent extraction systems were used: EtOAc, $70 \% \mathrm{EtOH}$, and distilled $\mathrm{H}_{2} \mathrm{O}$. All samples were sonicated twice for $30 \mathrm{~min}$ at $25^{\circ} \mathrm{C}$, and aliquots were filtered through a $0.2 \mu \mathrm{m}$ PTFE filter prior to use in enzymatic assays and liquid chromatography analyses. All of the extraction and chromatographic solvents employed were of LC-MS grade (J. T. Baker, Phillipsburg, NJ, USA). 


\subsection{Instruments}

${ }^{1} \mathrm{H}$ and ${ }^{13} \mathrm{C}$ NMR experiments were performed on a Bruker AM 400, using different solvents $\left(\mathrm{CD}_{3} \mathrm{OD}\right.$ and DMSO- $\left.d_{6}\right)$. The internal standard was tetramethylsilane (TMS) (Andover, MA, USA). HRESI mass spectra were obtained on a qToF mass spectrometer (qToF Premier ${ }^{\mathrm{TM}}$, Waters Corp., Milford, MA, USA). The UPLC system, equipped with a binary solvent delivery system, an autosampler, and a UV detector, was also from Waters Corp. Separations were carried out on a medium pressure liquid chromatography (MPLC) system (LC-forte/R; YMC Co., Ltd., Kyoto, Japan), where reversed-phase (RP) cartridges purchased from YMC were employed. For purification, preparative high-performance liquid chromatography (HPLC) was performed using a Gilson HPLC system (Gilson, Inc., Middleton, WI, USA) with a YMC octadecyl-functionalized silica gel-AQ column $(250 \mathrm{~mm} \times 20 \mathrm{~mm}$, i.d. $5 \mu \mathrm{m})$. A Multi-Mode Microplate Reader SpectraMax M2 (Molecular Devices, Sunnyvale, CA, USA) was used for the enzymatic assays.

\subsection{Sample Extraction, Fractionation, and Isolation}

The freeze-dried T. sinensis leaves (200 g) were cut into small pieces and extracted with $70 \%$ ethanol $(4 \mathrm{~L} \times 3)$ at room temperature. The combined extract was evaporated, resulting in $36.4 \mathrm{~g}$ (18.2\% yield) of crude extract. A $20 \mathrm{~g}$ sample of this extract was subjected to column chromatography on a Diaion HP20SS $(10 \times 40 \mathrm{~cm}, 750 \mathrm{~g})$, eluted with $\mathrm{MeOH} / \mathrm{H}_{2} \mathrm{O}$ mixtures [0:100 (1 L), 30:70 (1 L), 50:50 (2 L), 70:30 (2 L), 90:10 (1 L), and 100:0 (1 L)], to give six fractions (A-F). Fraction C (2.3 g) was fractionated on an RP column (120 g, C18 cartridge) using MPLC with a linear gradient of $30 \%-90 \%$ $\mathrm{MeOH} / \mathrm{H}_{2} \mathrm{O}$ at a flow rate of $20 \mathrm{~mL} / \mathrm{min}$ to afford eight fractions (C1-C8). Subfractions C3-C5, enriched with compounds $\mathbf{1}$ and 2, were combined (342 $\mathrm{mg}$ ) and further purified by Sephadex LH-20 with 70\% MeOH as the eluent, yielding compounds $1(49 \mathrm{mg})$ and 2 (112 mg). Fraction D (4.5 g) was fractionated via RP-MPLC using a C18 column cartridge (220 g) using a gradient of increasing $\mathrm{MeOH}$ (50\%-90\%) in $\mathrm{H}_{2} \mathrm{O}$ to give fractions D1-D11. Subfractions D4-C7, enriched with compounds 3 and 4, were combined (941 $\mathrm{mg}$ ) and further purified by preparative HPLC using $60 \% \mathrm{MeOH}$ as the mobile phase to afford compounds 3 (114 mg) and 4 (623 mg). Subsequent separation of fraction D9 (230 mg), enriched with compound 5, on Sephadex LH-20 with $80 \% \mathrm{MeOH}$ as eluent yielded compound 5 $(126 \mathrm{mg})$. The physicochemical and spectrometric data of the five compounds (1-5) were as follows:

Quercetin-3-O-rutinoside (1). Yellow powder; negative ESI-HRMS, $m / z$ : $609.1448[\mathrm{M}-\mathrm{H}]^{-}$(calcd for $\left.\mathrm{C}_{27} \mathrm{H}_{29} \mathrm{O}_{16} 609.1456\right) ;{ }^{1} \mathrm{H}$ NMR $\left(400 \mathrm{MHz}, \mathrm{DMSO}-d_{6}\right): \delta 7.56\left(1 \mathrm{H}, \mathrm{d}, J=2.1 \mathrm{~Hz}, \mathrm{H}-2^{\prime}\right), 7.53(1 \mathrm{H}$, $\left.\mathrm{dd}, J=2.1 \mathrm{~Hz}, 8.1 \mathrm{~Hz}, \mathrm{H}-6^{\prime}\right), 6.84\left(1 \mathrm{H}, \mathrm{d}, J=8.2 \mathrm{~Hz}, \mathrm{H}-5^{\prime}\right), 6.38(1 \mathrm{H}, \mathrm{d}, J=1.9 \mathrm{~Hz}, \mathrm{H}-8), 6.19(1 \mathrm{H}, \mathrm{d}$, $J=1.9 \mathrm{~Hz}, \mathrm{H}-6), 5.34\left(1 \mathrm{H}, \mathrm{d}, J=7.2 \mathrm{~Hz}, \mathrm{H}-1^{\prime \prime}\right), 4.39\left(\mathrm{~s}, \mathrm{H}-1^{\prime \prime \prime}\right), 3.70\left(2 \mathrm{H}, \mathrm{d}, J=9.7 \mathrm{~Hz}, \mathrm{H}-6^{\prime \prime}\right), 1.10(3 \mathrm{H}$, $\left.\mathrm{d}, J=6.1 \mathrm{~Hz}, \mathrm{CH}_{3}-6^{\prime \prime \prime}\right) ;{ }^{13} \mathrm{C}$ NMR (100 MHz, DMSO- $\left.d_{6}\right): \delta 178.1$ (s, C-4), 166.5 (s, C-7), 163.4 (s, C-5), 158.8 (s, C-9), 158.7 (s, C-2), 147.0 (s, C-4'), $144.5\left(\mathrm{~s}, \mathrm{C}-3^{\prime}\right), 135.6(\mathrm{~s}, \mathrm{C}-3), 123.8$ (d, C-6' $), 123.4\left(\mathrm{~s}, \mathrm{C}-1^{\prime}\right)$, $118.5\left(\mathrm{~d}, \mathrm{C}-5^{\prime}\right), 117.5\left(\mathrm{~d}, \mathrm{C}-2^{\prime}\right), 106.2(\mathrm{~s}, \mathrm{C}-10), 103.5\left(\mathrm{~d}, \mathrm{C}-1^{\prime \prime}\right), 103.0\left(\mathrm{~d}, \mathrm{C}-1^{\prime \prime \prime}\right), 100.9(\mathrm{~d}, \mathrm{C}-6), 95.9(\mathrm{~d}$, C-8), $78.7\left(\mathrm{~d}, \mathrm{C}-3^{\prime \prime}\right), 78.1\left(\mathrm{~d}, \mathrm{C}-5^{\prime \prime}\right), 76.3\left(\mathrm{~d}, \mathrm{C}-2^{\prime \prime}\right), 74.1\left(\mathrm{~d}, \mathrm{C}-4^{\prime \prime \prime}\right), 72.8\left(\mathrm{~d}, \mathrm{C}-3^{\prime \prime \prime}\right), 72.6\left(\mathrm{~d}, \mathrm{C}-2^{\prime \prime \prime}\right), 70.1(\mathrm{~d}$, $\left.\mathrm{C}-4^{\prime \prime}\right), 72.3\left(\mathrm{~d}, \mathrm{C}-5^{\prime \prime \prime}\right), 70.5\left(\mathrm{t}, \mathrm{C}-6^{\prime \prime}\right), 20.0\left(\mathrm{q}, \mathrm{C}-6^{\prime \prime \prime}\right)$.

Quercetin-3-O- $\beta$-D-glucopyranoside (2). Yellow powder; negative ESI-HRMS, $m / z$ : $463.0893[\mathrm{M}-\mathrm{H}]^{-}$ (calcd for $\left.\mathrm{C}_{21} \mathrm{H}_{19} \mathrm{O}_{12} 463.0877\right) ;{ }^{1} \mathrm{H}$ NMR (400 MHz, DMSO- $\left.d_{6}\right): \delta 7.59\left(1 \mathrm{H}, \mathrm{d}, J=2.0 \mathrm{~Hz}, \mathrm{H}-2^{\prime}\right), 7.58$ $\left(1 \mathrm{H}, \mathrm{dd}, J=2.0,8.8 \mathrm{~Hz}, \mathrm{H}-6^{\prime}\right), 6.86\left(1 \mathrm{H}, \mathrm{d}, J=8.8 \mathrm{~Hz}, \mathrm{H}-5^{\prime}\right), 6.40(1 \mathrm{H}, \mathrm{d}, J=2.0 \mathrm{~Hz}, \mathrm{H}-8), 6.20(1 \mathrm{H}$, $\mathrm{d}, J=2.0 \mathrm{~Hz}, \mathrm{H}-6), 5.47\left(1 \mathrm{H}, \mathrm{d}, J=7.4 \mathrm{~Hz}, \mathrm{H}-1^{\prime \prime}\right), 3.60-3.09$ (m, glc protons); ${ }^{13} \mathrm{C}-\mathrm{NMR}$ (DMSO- $d_{6}$, $100 \mathrm{MHz}) \delta 177.7$ (s, C-4), 164.7 (s, C-7), 161.6 (s, C-5), 156.7 (s, C-9), 156.5 (s, C-2), 148.8 (s, C-4'), 145.2 (s, C-3'), 133.7 (s, C-3), $121.9\left(\mathrm{~s}, \mathrm{C}-\mathrm{1}^{\prime}\right), 121.5\left(\mathrm{~d}, \mathrm{C}-6^{\prime}\right), 116.5$ (d, C-2'), $115.6\left(\mathrm{~d}, \mathrm{C}-5^{\prime}\right), 104.3(\mathrm{~s}, \mathrm{C}-10), 101.2$ $\left(\mathrm{d}, \mathrm{C}-1^{\prime \prime}\right), 99.1(\mathrm{~d}, \mathrm{C}-6), 93.9(\mathrm{~d}, \mathrm{C}-8), 77.9\left(\mathrm{~d}, \mathrm{C}-5^{\prime \prime}\right), 76.9\left(\mathrm{~d}, \mathrm{C}-3^{\prime \prime}\right), 74.4\left(\mathrm{~d}, \mathrm{C}-2^{\prime \prime}\right), 70.3\left(\mathrm{~d}, \mathrm{C}-4^{\prime \prime}\right), 61.3$ $\left(\mathrm{t}, \mathrm{C}-6^{\prime \prime}\right)$.

1,2,3,4,6-penta-O-galloyl- $\beta$-D-glucopyranose (3). White powder; negative ESI-HRMS, $m / z$ : 939.1119 $[\mathrm{M}-\mathrm{H}]^{-}$(calcd for $\mathrm{C}_{41} \mathrm{H}_{31} \mathrm{O}_{26}$ 939.1104); ${ }^{1} \mathrm{H}$ NMR (400 MHz, $\left.\mathrm{CD}_{3} \mathrm{OD}\right): \delta 7.13,7.07,6.99,6.97,6.92$ 
(each 2H, s, galloyl H-2, 6), $6.26\left(1 \mathrm{H}, \mathrm{d}, J=8.4 \mathrm{~Hz}, \mathrm{H}-1^{\prime}\right), 5.93\left(1 \mathrm{H}, \mathrm{t}, J=9.5,9.6 \mathrm{~Hz}, \mathrm{H}-3^{\prime}\right), 5.65(1 \mathrm{H}, \mathrm{t}$, $\left.J=8.7,9.5 \mathrm{~Hz}, \mathrm{H}-4^{\prime}\right), 5.60\left(1 \mathrm{H}, \mathrm{dd}, J=8.5,9.6 \mathrm{~Hz}, \mathrm{H}-2^{\prime}\right), 4.53\left(1 \mathrm{H}, \mathrm{d}, J=10.8 \mathrm{~Hz}, \mathrm{H}-5^{\prime}\right), 4.38-4.46(2 \mathrm{H}, \mathrm{m}$, H-6 $\left.{ }^{\prime}\right) ;{ }^{13} \mathrm{C}$ NMR $\left(100 \mathrm{MHz}, \mathrm{CD}_{3} \mathrm{OD}\right.$ ): $\delta 168.3,167.7,167.4,167.3,166.6$ (each s, C-7), 147.0, 146.9, 146.8, 146.7, 146.6 (each s, C-3, 5), 141.2, 140.8, 140.7, 140.5, 140.4 (each s, C-4), 121.4, 120.7, 120.6, 120.5, 120.1 (each s, C-1), 110.9, 110.8, 110.7, 110.7, 110.6 (each d, C-2, 6), $94.2\left(\mathrm{~d}, \mathrm{C}-1^{\prime}\right), 74.8\left(\mathrm{~d}, \mathrm{C}-5^{\prime}\right), 74.5\left(\mathrm{~d}, \mathrm{C}-3^{\prime}\right)$, $72.6\left(\mathrm{~d}, \mathrm{C}-2^{\prime}\right), 70.1\left(\mathrm{~d}, \mathrm{C}-4^{\prime}\right), 63.5\left(\mathrm{t}, \mathrm{C}-6^{\prime}\right)$.

Quercetin-3-O- $\alpha$-L-rhamnopyranoside (4). Yellow powder; negative ESI-HRMS, $m / z$ : $447.0939[\mathrm{M}-\mathrm{H}]^{-}$ (calcd for $\mathrm{C}_{21} \mathrm{H}_{19} \mathrm{O}_{11}$ 447.0927); ${ }^{1} \mathrm{H}$ NMR (400 MHz, DMSO- $\left.d_{6}\right): \delta 7.30\left(1 \mathrm{H}, \mathrm{d}, J=2.0 \mathrm{~Hz}, \mathrm{H}-2^{\prime}\right), 7.26$ $\left(1 \mathrm{H}, \mathrm{dd}, J=2.0,8.8 \mathrm{~Hz}, \mathrm{H}-6^{\prime}\right), 6.87\left(1 \mathrm{H}, \mathrm{d}, J=8.4 \mathrm{~Hz}, \mathrm{H}-5^{\prime}\right), 6.39(1 \mathrm{H}, \mathrm{d}, J=1.2 \mathrm{~Hz}, \mathrm{H}-8), 6.20(1 \mathrm{H}, \mathrm{d}$,


$3.14\left(\mathrm{~m}, \mathrm{H}-4^{\prime \prime}\right), 0.82\left(3 \mathrm{H}, \mathrm{d}, J=6.0 \mathrm{~Hz}, \mathrm{H}-6^{\prime \prime}\right) ;{ }^{13} \mathrm{C}-\mathrm{NMR}$ (DMSO- $\left.d_{6}, 100 \mathrm{MHz}\right) \delta 178.1$ (s, C-4), 164.7 (s, C-7), 161.6 (s, C-5), 157.6 (s, C-9), 156.8 (s, C-2), 148.8 (s, C-4'), 145.6 (s, C-3'), 134.6 (s, C-3), 121.5 (s, C-1'), $121.1\left(\mathrm{~d}, \mathrm{C}-6^{\prime}\right), 115.9\left(\mathrm{~d}, \mathrm{C}-5^{\prime}\right), 115.8\left(\mathrm{~d}, \mathrm{C}-2^{\prime}\right), 104.4(\mathrm{~s}, \mathrm{C}-10), 102.2\left(\mathrm{~d}, \mathrm{C}-1^{\prime \prime}\right), 99.1(\mathrm{~d}, \mathrm{C}-6), 94.0(\mathrm{~d}$, C-8), $71.5\left(\mathrm{~d}, \mathrm{C}-4^{\prime \prime}\right), 70.9\left(\mathrm{~d}, \mathrm{C}-3^{\prime \prime}\right), 70.7\left(\mathrm{~d}, \mathrm{C}-2^{\prime \prime}\right), 70.4\left(\mathrm{~d}, \mathrm{C}-5^{\prime \prime}\right), 17.9\left(\mathrm{q}, \mathrm{C}-6^{\prime \prime}\right)$.

Kaempferol-3-O- $\alpha$-L-rhamnopyranoside (5). Yellow powder; negative ESI-HRMS, $m / z$ : $431.0974[\mathrm{M}-\mathrm{H}]^{-}$ (calcd for $\left.\mathrm{C}_{21} \mathrm{H}_{19} \mathrm{O}_{10} 431.0978\right) ;{ }^{1} \mathrm{H}$ NMR $\left(400 \mathrm{MHz}\right.$, DMSO- $\left.d_{6}\right): \delta 7.76\left(2 \mathrm{H}, \mathrm{d}, J=8.8 \mathrm{~Hz}, \mathrm{H}-2^{\prime}, 6^{\prime}\right), 6.92$ $\left(2 \mathrm{H}, \mathrm{d}, J=8.8 \mathrm{~Hz}, \mathrm{H}-3^{\prime}, 5^{\prime}\right), 6.42(1 \mathrm{H}, \mathrm{d}, J=2.0 \mathrm{~Hz}, \mathrm{H}-8), 6.21(1 \mathrm{H}, \mathrm{d}, J=2.0 \mathrm{~Hz}, \mathrm{H}-6), 5.30(1 \mathrm{H}, \mathrm{br} \mathrm{s}$, $\left.\mathrm{H}-1^{\prime \prime}\right), 3.99\left(1 \mathrm{H}, \mathrm{br} \mathrm{s}, \mathrm{H}-2^{\prime \prime}\right), 3.48\left(1 \mathrm{H}, \mathrm{d}, J=6.4 \mathrm{~Hz}, \mathrm{H}-3^{\prime \prime}\right), 3.15-3.07\left(2 \mathrm{H}, \mathrm{m}, \mathrm{H}-4^{\prime \prime}, 5^{\prime \prime}\right), 0.80(3 \mathrm{H}, \mathrm{d}$, $\left.J=6.0 \mathrm{~Hz}, \mathrm{H}-6^{\prime \prime}\right) ;{ }^{13} \mathrm{C}-\mathrm{NMR}$ (DMSO- $\left.d_{6}, 100 \mathrm{MHz}\right) \delta 178.1$ (C-4), 164.6 (C-7), 161.6 (C-5), 160.3 (C-4'), 157.6 (C-9), 156.9 (C-2), 134.6 (C-3), $130.9\left(\mathrm{C}-2^{\prime}, 6^{\prime}\right), 120.9$ (C-1'), $115.7\left(\mathrm{C}-3^{\prime}, 5^{\prime}\right), 104.5$ (C-10), 102.1 $\left(\mathrm{C}-1^{\prime \prime}\right), 99.1(\mathrm{C}-6), 94.1(\mathrm{C}-8), 71.5\left(\mathrm{C}-4^{\prime \prime}\right), 70.9\left(\mathrm{C}-2^{\prime \prime}\right), 70.7\left(\mathrm{C}-3^{\prime \prime}\right), 70.4\left(\mathrm{C}-5^{\prime \prime}\right), 17.8\left(\mathrm{C}-6^{\prime \prime}\right)$.

\subsection{UPLC-qToF MS Analysis}

The identification of component peaks was carried out by UPLC using a photodiode array detector. Test sample aliquots $(2.0 \mu \mathrm{L})$ were then injected into a C18 BEH column $(2.1 \times 100 \mathrm{~mm}, 1.7 \mu \mathrm{m})$ at a flow rate of $0.4 \mathrm{~mL} / \mathrm{min}$. The mobile phase consisted of water/acetonitrile $(\mathrm{ACN})$ containing $0.1 \%$ formic acid. The linear gradient was as follows: $0-1 \mathrm{~min}, 10 \% \mathrm{ACN} ; 1-10 \mathrm{~min}, 10-40 \% \mathrm{ACN}$; 10-11.3 $\mathrm{min}, 40-100 \% \mathrm{ACN} ; 11.3-13.3 \mathrm{~min}, 100 \% \mathrm{ACN} ; 13.3-15 \mathrm{~min}$, return to $10 \% \mathrm{ACN}$. The qToF MS was operated in negative-ion mode under the following conditions: Source temperature, $110{ }^{\circ} \mathrm{C}$; cone voltage, $45 \mathrm{~V}$; capillary voltage, $2.5 \mathrm{kV}$. The full-scan data and MS/MS spectra were collected using MassLynx software (Waters Corp.).

\subsection{In Vitro XO Assay}

XO activity was assayed spectrophotometrically on a Spectra Max M2 microplate reader, using published experimental procedures, with slight modifications. First, $135 \mu \mathrm{L}$ of $100 \mathrm{mM}$ sodium pyrophosphate buffer ( $\mathrm{HCl}, \mathrm{pH} 7.5), 20 \mu \mathrm{L}$ of 0.2 unit XO enzyme (bovine milk) in buffer, and $5 \mu \mathrm{L}$ of sample (test extract or compound) in DMSO were mixed at $37^{\circ} \mathrm{C}$. The reaction was started by adding $40 \mu \mathrm{L}$ of substrate $(0.5 \mathrm{mM}$ xanthine) in buffer to the mixture. The reaction mixture $(200 \mu \mathrm{L})$ was incubated at $37^{\circ} \mathrm{C}$ in a $300 \mu \mathrm{L}$ well plate, and the UV absorbance was determined at $295 \mathrm{~nm}$. Allopurinol, a known inhibitor of $\mathrm{XO}$, served as a positive control.

\subsection{Induction of Hyperuricemia and Sample Treatment}

Male Sprague-Dawley rats (7 weeks old) were purchased from Orient Bio (Seongmam, Korea) and were housed at a temperature of $22 \pm 1{ }^{\circ} \mathrm{C}$ with $50 \pm 10 \%$ humidity under a $12 \mathrm{~h}$ light/dark cycle with free access to a laboratory diet and water. The experimental design was approved by the Committee on Animal Care of the Korea Institute of Oriental Medicine, and all experiments were performed in accordance with committee guidelines. The uricase inhibitor PO was administered to induce hyperuricemia. The rats were divided into the following five groups ( $n=6 /$ group): (1) Normal control group; (2) PO-treated control group; (3) PO $+300 \mathrm{mg} / \mathrm{kg}$ TSE group; (4) $\mathrm{PO}+40 \mathrm{mg} / \mathrm{kg}$ 
compound 3 group; (5) $\mathrm{PO}+10 \mathrm{mg} / \mathrm{kg}$ allopurinol group. The rats in groups 2-5 were injected intraperitoneally with $150 \mathrm{mg} / \mathrm{kg}$ PO prepared in $0.5 \% \mathrm{CMC}$ with $0.1 \mathrm{M}$ sodium acetate (pH 5.0) to induce hyperuricemia, and the normal control rats were treated with $0.5 \% \mathrm{CMC}$ with $0.1 \mathrm{M}$ sodium acetate. TSE, compound 3, and allopurinol were dispersed in $0.5 \%$ CMC and administered by oral gavage $1 \mathrm{~h}$ after $\mathrm{PO}$ injection.

\subsection{Serum Uric Acid Analysis}

Blood samples were collected via cardiac puncture under anesthesia $2 \mathrm{~h}$ after oral treatment. Serum was obtained by centrifugation of blood at $3000 \times g$ for $10 \mathrm{~min}$ at $4{ }^{\circ} \mathrm{C}$. The separated serum was stored at $-80{ }^{\circ} \mathrm{C}$ until analysis. Serum uric acid levels were determined by an enzymatic-colorimetric method using a commercial assay kit (Biovision, Milpitas, CA, USA) according to the manufacturer's protocol.

\subsection{Statistical Analysis}

All measurements of in vitro XO activity and individual compound levels were conducted in triplicate. Data are expressed as the mean \pm standard deviation using Sigma plot 10.0 software (Systat Software Inc., San Jose, CA, USA). In vivo data are expressed as the mean \pm standard error of the mean. Differences between the control and treatment groups were analyzed by one-way analysis of variance, Dunnett's multiple comparison test was applied to determine significance using Prism 7.0 (GraphPad Software Inc., San Diego, CA, USA), and $p<0.05$ was considered statistically significant.

\section{Conclusions}

TSE had a significant inhibitory effect on $\mathrm{XO}$ in vitro and produced a significant hypouricemic effect on rats with PO-induced hyperuricemia in vivo. Importantly, the main active component of TSE was found to be pentagalloyl glucose (3), which showed strong inhibition $\left(\mathrm{IC}_{50}=2.79 \mu \mathrm{M}\right)$ of XO and also lowered serum uric acid levels in rats with PO-induced hyperuricemia. Based on our detailed kinetic analyses using double-reciprocal plots, compound 3 was a noncompetitive inhibitor with a $K_{i}$ of $3.1 \mu \mathrm{M}$. Compound 3 was present at a level of $1.34 \mathrm{mg} / \mathrm{g}$ of dried TSE. These findings suggest that T. sinensis leaves could be developed to produce health foods and nutraceuticals.

Supplementary Materials: The following are available online: Figure S1-S5: ${ }^{1} \mathrm{H}-\mathrm{NMR}$ spectrum of compounds (1-5); Figure S6-S10: ${ }^{13}$ C-NMR spectrum of compounds (1-5); Figure S11-S15: Identification of compounds (1-5) by UPLC-qTof MS; Figure S16: Effects of compound 4 (40 mg/kg) on serum uric acid levels in PO-induced hyperuricemic rats.

Author Contributions: H.J.Y. performed the experiments, analyzed the data, and wrote the manuscript. Y.-S.L. performed the experiments, analyzed the data, and contributed to discussions. H.W.R. analyzed the UPLC and wrote the manuscript. S.-H.K. contributed to discussions and reviewed the manuscripts. This study was performed based on the design of D.-S.K., the corresponding author. All authors approved the final manuscript.

Funding: This research was supported by a grant from the Korea Institute of Oriental Medicine (K18030), funded by the Korean government (Ministry of Science and ICT).

Conflicts of Interest: The authors declare no conflict of interest.

\section{References}

1. Gibson, T. Hyperuricemia, gout and the kidney. Curr. Opin. Rheumatol. 2012, 24, 127-131. [CrossRef] [PubMed]

2. Bitik, B.; Öztürk, M.A. An old disease with new insights: Update on diagnosis and treatment of gout. Eur. J. Rheumatol. 2014, 1, 72-77. [CrossRef] [PubMed]

3. Martillo, M.A.; Nazzal, L.; Crittenden, D.B. The crystallization of monosodium urate. Curr. Rheumatol. Rep. 2014, 16, 400. [CrossRef] [PubMed] 
4. Redon, P.; Maloberti, A.; Facchetti, R.; Redon, J.; Lurbe, E.; Bombelli, M.; Mancia, G.; Grassi, G. Gender-related differences in serum uric acid in treated hypertensive patients from central and east European countries: findings from the blood pressure control rate and cardiovascular risk profile study. J. Hypertens. 2018. [CrossRef] [PubMed]

5. Maloberti, A.; Maggioni, S.; Occhi, L.; Triglione, N.; Panzeri, F.; Nava, S.; Signorini, S.; Falbo, R.; Casati, M.; Grassi, G.; Giannattasio, C. Sex-related relationships between uric acid and target organ damage in hypertension. J. Clin. Hypertens. (Greenwich). 2018, 20, 193-200. [CrossRef] [PubMed]

6. Fukunari, A.; Okamoto, K.; Nishino, T.B.; Eger, T.; Pai, E.F.; Kamezawa, M.; Yamada, I.; Kato, N. Y-700 [1-[3-Cyano-4-(2,2-dimethylpropoxy)phenyl]-1H-pyrazole-4-carboxylic acid]: A potent xanthine oxidoreductase inhibitor with hepatic excretion. J. Pharmacol. Exp. Ther. 2004, 311, 519-528. [CrossRef] [PubMed]

7. Terkeltaub, R.A. Clinical practice. Gout. N. Engl. J. Med. 2003, 349, 1647-1655. [CrossRef]

8. Huo, L.N.; Wang, W.; Zhang, C.Y.; Shi, H.B.; Liu, Y.; Liu, X.H.; Guo, B.H.; Zhao, D.M.; Gao, H. Bioassy-guided isolation and identification of xanthine oxidase inhibitory constituents from the leaves of Perilla frutescens. Molecules 2015, 20, 17848-17859. [CrossRef]

9. Chen, C.M.; Lin, C.Y.; Lin, L.C.; Wan, T.C. Antioxidation activity and total phenolic contents of various Toona sinensis extracts. Afr. J. Biotechnol. 2012, 11, 13831-13837. [CrossRef]

10. Hsieh, T.J.; Wang, J.C.; Hu, C.Y.; Li, C.T.; Kuo, C.M.; Hsieh, S.L. Effects of rutin from Toona sinensis on the immune and physiological responses of white shrimp (Litopenaeus vannamei) under Vibrio alginolyticus challenge. Fish Shellfish Immunol. 2008, .25, 581-588. [CrossRef]

11. Hsieh, T.J.; Liu, T.Z.; Chia, Y.C.; Chern, C.L.; Lu, F.J.; Chuang, M.C.; Mau, S.Y.; Chen, S.H.; Syu, Y.H.; Chen, C.H. Protective effect of methyl gallate from Toona sinensis (Meliaceae) against hydrogen peroxide-induced oxidative stress and DNA damage in MDCK cells. Food Chem. Toxicol. 2004, 42, 843-850. [CrossRef] [PubMed]

12. You, H.L.; Chen, C.J.; Eng, H.L.; Liao, P.L.; Huang, S.T. The effectiveness and mechanism of Toona sinensis extract inhibit attachment of pandemic influenza A (H1N1) virus. Evid Based Complement Alternat. Med. 2013. [CrossRef] [PubMed]

13. Gomes, C.A.; da Cruz, T.G.; Andrade, J.L.; Milhazes, N.; Borges, F.; Marques, M.P. Anticancer activity of phenolic acids of natural or synthetic origin: A structure-activity study. J. Med. Chem. 2003, 46, 5395-5401. [CrossRef] [PubMed]

14. Serafini, M.; Peluso, I.; Raguzzini, A. Flavonoids as anti-inflammatory agents. Proc. Nutr. Soc. 2010, 69, 273-278. [CrossRef] [PubMed]

15. Kim, D.W.; Curtis-Long, M.J.; Yuk, H.J.; Wang, Y.; Song, Y.H.; Jeong, S.H.; Park, K.H. Quantitative analysis of phenolic metabolites from different parts of Angelica keiskei by HPLC-ESI MS/MS and their xanthine oxidase inhibition. Food Chem. 2014, 153, 20-27. [CrossRef] [PubMed]

16. Wei, X.H.; Yang, S.J.; Liang, N.; Hu, D.Y.; Jin, L.H.; Xue, W.; Yang, S. Chemical constituents of Caesalpinia decapetala (Roth) Alston. Molecules 2013, 18, 1325-1336. [CrossRef] [PubMed]

17. Liu, H.; Mou, Y.; Zhao, J.; Wang, J.; Zhou, L.; Wang, M.; Wang, D.; Han, J.; Yu, Z.; Yang, F. Flavonoids from Halostachys caspica and their antimicrobial and antioxidant activities. Molecules 2010, 15, 7933-7945. [CrossRef]

18. Beretta, G.; Artali, R.; Caneva, E.; Maffei Facino, R. Conformation of the tridimensional structure of 1,2,3,4,6-pentagalloyl- $\beta$-D-glucopyranose (PGG) by ${ }^{1} \mathrm{H}$ NMR, NOESY and theoretical study and membrane interaction in a simulated phospholipid bilayer: a first insight. Magn. Reson. Chem. 2011, 49, 132-136. [CrossRef]

19. Saldanha, L.L.; Vilegas, W.; Dokkedal, A.L. Characterization of flavonoids and phenolic acids in Myrcia bella Cambess. using FIA-ESI-IT-MS(n) and HPLC-PAD-ESI-IT-MS combined with NMR. Molecules 2013, 18, 8402-8416. [CrossRef]

20. Lee, S.Y.; So, Y.J.; Shin, M.S.; Cho, J.Y.; Lee, J. Antibacterial effects of afzelin isolated from Cornus macrophylla on Pseudomonas aeruginosa, a leading cause of illness in immunocompromised individuals. Molecules 2014, 19, 3173-3180. [CrossRef]

21. Serna, D.M.; Martínez, J.H. Phenolics and Polyphenolics from Melastomataceae Species. Molecules 2015, 20, 17818-17847. [CrossRef] [PubMed] 
22. Sun, J.; Liu, X.; Yang, T.; Slovin, J.; Chen, P. Profiling polyphenols of two diploid strawberry (Fragaria vesca) inbred lines using UHPLC-HRMS ${ }^{n}$. Food Chem. 2014, 146, 289-298. [CrossRef] [PubMed]

23. Cos, P.; Ying, L.; Calomme, M.; Hu, J.P.; Cimanga, K.; Van Poel, B.; Pieters, L.; Vlietinck, A.J.; Vanden Berghe, D. Structure-activity relationship and classification of flavonoids as inhibitors of xanthine oxidase and superoxide scavengers. J. Nat. Prod. 1998, 61, 71-76. [CrossRef] [PubMed]

24. Liu, K.; Wang, W.; Guo, B.H.; Gao, H.; Liu, Y.; Liu, X.H.; Yao, H.L.; Cheng, K. Chemical evidence for potent xanthine oxidase inhibitory activity of ethyl acetate extract of Citrus aurantium L. dried immature fruits. Molecules 2016, 21, 302. [CrossRef] [PubMed]

25. Tamta, H.; Kalra, S.; Mukhopadhyay, A.K. Biochemical characterization of some pyrazolopyrimidine-based inhibitors of xanthine oxidase. Biochemistry (Mosc.) 2006, 71, S49-S54. [CrossRef] [PubMed]

26. Borges, F.; Fernandes, E.; Roleira, F. Progress towards the discovery of xanthine oxidase inhibitors. Curr. Med. Chem. 2002, 9, 195-217. [CrossRef]

27. Mo, S.F.; Zhou, F.; Lv, Y.Z.; Hu, Q.H.; Zhang, D.M.; Kong, L.D. Hypouricemic action of selected flavonoids in mice: structure-activity relationships. Biol. Pharm. Bull. 2007, 30, 1551-1556. [CrossRef]

Sample Availability: Not available. 